\title{
Self and the other in the Confucian cultural context: Implications of China's higher education development for comparative studies
}

\begin{abstract}
Contemporary comparative and international studies of higher education have overwhelmingly portrayed the powerful influence of economic and political realities. Cultural dimensions, especially those of traditional ways of thinking, have often been ignored, despite their omnipresence. Adopting the lens of traditional Chinese cultural thinking, this article offers an alternative perspective to look at China's higher education reform and development. It demonstrates how a different historical trajectory of higher education development resulted from the traditional Chinese way of thinking. With its own priorities, such a unique tradition does not coexist easily with the globally dominant European-North American university model. As universities are culturally embedded, it is erroneous to treat them as the same entity in various cultural contexts. This article examines the tensions in the interactions in higher education between the traditional Chinese and the imposed Western modes of thinking. Borrowing a thesis of the structure of culture, it reveals the various extents to which layers of Chinese higher education have achieved differently. It finds that with a strong catch-up mentality, China's contemporary higher education policies are responsive. They are panic-stricken and expedient band-aid remedies, rather than strategies based on systematic understandings of cultural contexts. Accordingly, Chinese universities are uncritical towards the European-American model and its variants. This article warns that without an infusion of traditional education values, universities in China risk losing touch with their cultural contexts in their quest for world-class status.
\end{abstract}

Keywords Context, Culture, Ways of thinking, Comparative studies, Higher education, China

\section{Introduction}

Concern with the context is the most enduring characteristic of disciplined comparative and international studies in education. With intensified globalisation, "context matters" (Crossley with Jarvis 2001) even more. While the critical role of context has been widely recognised (Yang 2007), a general stress on the importance of context does not suffice. Context means different things to different people. Indeed, inconsistencies in the use of context are common in the literature of comparative and international education. They can even be found within the same piece of work. Focusing on the researcher, context has much to do with positionality, dealing with issues of being an insider or an outsider. Early thinkers insisted on the need for and the possibility of distinguishing the 'natives' and the strangers, because in their eye the differences between the researchers and the researched were obvious (see, for example, Mead 1929). However, the distinctions become blurred when research is conducted in a familiar context of "the culture, gender, religions, residential and ethnic backgrounds" of the researcher (Hockey 1993, p. 201). In an era of a global cultural economy with increasing disjuncture and differences (Appadurai 1990), this issue becomes even more problematic.

The insider-outsider dichotomy does not always help. Individuals from one community with access to a particular form of cultural cognition do not naturally attach authority to this 
cognition (Kreiger 1982). Outsiders do not necessarily see less. Indeed, they could see more by avoiding the familiar scenario that when people are extremely close to some subjects they tend not to see what those equivalents are. In this sense, outsiderness can shed light on information that may otherwise have been overlooked (Bridges 2001). Moreover, individuals do not have a single status only. Instead, they have a status set (Merton 1972). A key concern is the relationship between one's own cultural cognition and that of the culturally different society s/he studies. Individual researchers need to be aware of their own cultural conditioning, keen not to overlook the different cognitive frameworks of the participants, and address questions about their beliefs and attitudes through appropriate lenses.

Context is multidimensional. Comparative education researchers usually pay much attention to social, cultural, economic and political contexts. Among the various dimensions, culture has been the most prominent and attracted particular attention, although the term itself remains one of the most elusive entities in social research and has often been misunderstood and misused. One of the most cited definitions is by Dutch anthropologist Geert Hofstede (1981) who defines culture as "the collective programming of the human mind that distinguishes the members of one human group from those of another." Culture therefore is "a system of collectively held values” (p. 24). Such a functionalist bipolar paradigm of analysing national cultures (see, for example, Hofstede 1991, 2001) has long been dominant in the field of international cross-cultural education. Dividing national cultures into individualist or collectivist types represents a static and deterministic vision of culture; this view has increasingly become at odds with today's global cross-cultural education environment.

Cultural context needs to be viewed as layered, with three aspects included in culture in its anthropological sense: material, social (institutional) and ideological. Built on the thesis by Liang Shuming's three aspects of culture-material, social and spiritual life (Cao 1994), Pang Pu (1986) coined "the structure of culture" (p. 25), that is, a culture, regardless of its type, stage or evolution, consists of three levels: at the outset there is the material level; at the core (the deepest level) is the psychological or ideological level; in the middle is the combination of the two: materialised ideology, such as theory, system, and behaviour. This view is particularly useful in the studies of cross-cultural interactions of educational theory, policy and practice. According to it, culture is never static. Contacts and communication between cultures begin at the material level and gradually influence the social and ideological culture. As the material culture is constantly progressing, the social and ideological culture is also changing. Culture at the third level is deeply rooted in a nation's tradition and ideology and resistant to change. It is this relative stability of the core aspect of culture which makes it possible to discuss the varieties of culture. But being stable does not mean that it is static. History moves forward; so does culture.

For comparative studies, the way people view others and how they interact with the natural world have significant implications. The science or art of comparative analysis treads the space between self and other (Welch 2010). According to Nisbett (2003), independent and interdependent thinking are allied respectively to people of North American and East Asian culture. Utilising comparative analysis of how Westerners and East Asians viewed the world within an animated simulation of the view in a fish tank, he finds that East Asians tend to pay much more attention to the background elements in the animated vignette, rather than focusing primarily on the fish that comprised much of the foreground of the scene. Asians view the world through a wide angle lens, whereas Westerners have tunnel vision. They were faster in identifying the existence of and changes in relationships between objects or events within the background of a scene, and were more "field dependent" than Westerners in making a judgment 
of a situation, requiring context to be able to make an evaluation in the first place. Their cultural thinking has significant implications for how they treat foreign educational experiences. For example, Japanese reaction to the policy suggestions from the United States during American occupation after the World War II contrasted markedly to the German attitude: while the former took almost all the advices the latter made highly selective choices.

Another way of cultural thinking that exerts great impact on educational development and by extension possesses implications for comparative studies is through attitudes towards the natural world. Here, Chinese and Angelo-Saxon cultures serve as telling examples. While Chinese sages have always taught people to concentrate on human society only, their AngloSaxon counterparts have been committed to exploring the nature. Therefore, unlike the outwardlooking Western thinking, the central attention of the Chinese way of thinking has been inwardlooking, confined almost exclusively to human behaviours. Such different orientations of cultural thinking have led to different historical trajectories of higher education. In the case of China's higher education development, the dilemma is while Chinese culture's lack of interest in exploring the natural world led to a unique higher education tradition that contradicts fundamentally with the Western, the interdependent Chinese cultural thinking has fostered a social and policy environment to widely accept the dominant European-North American university model in China, as shown later.

Hajime Nakamura (1964) once remarked that "while every individual is affected by the quickening flow of world events, he is still strongly influenced by the way of living and thinking in his own nation and culture” (p. 3). With increasingly intensified globalisation, the flow of world events has only become more rapid, while individuals remain greatly influenced by their ways of cultural thinking. This is especially the case for people working at cultural institutions such as universities. However, contemporary comparative and international studies of higher education reforms have been overwhelmed by the powerful influence of economic and political realities. Focusing on the impact of Chinese traditional ways of viewing self, the other and the nature on higher education development, this article traces contemporary practices to their historical and cultural roots, and delves deep into the current reform endeavours. It reveals that China's rich traditional culture has caused great difficulty in indigenising the imposed Western concept of the university.

\section{Chinese Cultural Thinking and Its Impact on Higher Education Development}

When first encountering The Book of Changes (易 經), the late great Swiss psychiatrist Carl Gustav Jung (1875-1961) sighed that for a people as intelligent as the Chinese during early times, why had they failed to develop what we call science and technology today. To me, the reason lies in the differences of cultural thinking. While ancient Western thinkers endeavoured to explore the outside world, such as the obsession of ancient Greek philosophers with the celestial phenomena, their Chinese counterparts chose an inward-looking path. As posited by Mencius, people would understand the natural world perfectly if they understand themselves well. This reflects important differences in how the two cultures understand human action in the world. Understanding oneself as part of the world instead of as outside it, the Chinese worldview does not view humans as distinct from the world (Henkel 2006). Unlike the emphasis on exploration of the natural world in the origins of Western culture, moving from nature to the human world, the Chinese culture has centred on humans, moving from humans to nature. A severe dichotomy 
between theory and practice is not present in Chinese thought. The Chinese view of the world as continual and in process.

According to Jullien (2004, p. 189), the basic difference between Western and Chinese thought is that "one constructs a model that is then projected onto the situation, which implies that the situation is momentarily 'frozen.' The other relies on the situation as on a disposition that is known to be constantly evolving." Noting the different relation of humans to nature in the West and in the East as one of the salient contrasts between the two civilisations, Fairbank (1983, p. 14) wrote:

Man has been in the center of the Western stage. The rest of nature has served as neutral background or as his adversary. Thus Western religion is anthropomorphic and early Western painting anthropocentric. To see how great this gulf is we have only to compare Christianity with the relative impersonality of Buddhism, or a Sung landscape and its tiny human figures dwarfed by crags and rivers with an Italian primitive in which nature is an afterthought.

Such a mode of thinking has had a strong impact on the historical development of China's higher education. Firstly, it led to the unique historical roots of Chinese higher education. China's higher education had evolved according to its own logic and never deviated from its developmental path, despite external influences. By the $18^{\text {th }}$ century, China had developed a unique set of scholarly values over its 2,000 years of imperial history. Over such a long process, its higher education circles confined their dissemination of knowledge to the provincial level and persisted in disregarding knowledge about anything in the rest of the world. There was no institution in Chinese tradition that could be called a university. Instead, the imperial examination system $^{1}$ and the academies or shuyuan ${ }^{2}$ were key elements of ancient Chinese higher learning (Hayhoe 1996, p. 10).

With the diffusion of the European model of the university throughout much of the world under conditions of imperialism and colonialism in the $19^{\text {th }}$ century, China's higher education could have taken the lead in introducing and assimilating advanced culture, science and technology to promote social and economic development. Instead, due to its exclusivity, Chinese higher education continued to train traditional Confucian scholars with little knowledge of the outside world. Although Western higher education models had already demonstrated their strength, China's communication with the West was intentionally hindered. Chinese higher education within the period laid stress solely on the training of scholars with an encyclopedic knowledge based on Confucian values, which in practice served only the aristocracy (Yang 2002). The Confucian scholars acquired the education that symbolised their social status. Secondly, lacking an interest in seeking knowledge for its own sake, traditional Chinese higher education placed its central focus on utility, in the terms of the ruling classes. After

\footnotetext{
${ }^{1}$ The imperial examination system began to take form around 400 C.E. and reached its full institutional development in the Tang dynasty (618-907 C.E.). During the Song (960-1279 C.E.), it crystallised into patterns that were to last right up to 1911. For more information, see Ruth Hayhoe’s (1996) China's Universities 1895-1995, especially page 10 .

2 The academies or shuyuan took their definitive forms in the Song dynasty, as what had been originally libraries or centres for scholarly discussion developed into academies that provided a structured learning environment separate from, yet interacting with, state institutions associated with the civil service examination system. See also Ruth Hayhoe’s (1996) China’s Universities 1895-1995 on page 11 for more information.
} 
unifying China, Qin dynasty banned private schooling, allowed only to study from officials (以 吏為師), and made imperial power supreme. Emperor Wu of Han (漢武帝, 156-87 BC) adopted an advice by Dong Zhongshu (董仲舒, 179-104 BC) to revere only Confucianism and dismissed all the Hundred Schools of Thoughts (罷黜百家, 獨尊儒術). Dong recommended Taixue (太學) as the best place to restore talents with its essential task to influence (教化) (Meng 1996, p. 140), a place not only to train talents, but also to exert influence and select political personnel. Meanwhile, Gongsun Hong (公孫弘, 200-121 BC), the then prime minister, suggested the government establish a system of scholars with disciples (博士弟子員制度) so that local communities would be positively influenced while talents were rewarded. Emperor Wu took their advices, and ordered to establish Taixue in 124 BC to host scholars and their students, with a hope that they would set a good example for the entire society.

Taixue taught Confucianism (Ebrey 1999). Even after one year of study at Taixue with mastery of one classic, students were eligible to be chosen by the government to become officials. By so doing, the government directly controlled their political future. This was the beginning of China's strong tradition for more than two thousand years-higher education aiming at preparing would-be officials for the state. Taixie thus became a subsidiary body of the bureaucratic system (Zhang 2009, p. 18). As part of the ruling system, Taixue neither could nor attempted to go beyond the imperial framework. The first nationwide government school system in China was established in 3 CE under Emperor Ping of Han, with the Taixue on the top located in the capital of Chang'an (Yuan 1994). Later, it was replaced by the Guozijian (國子監) as the top level of educational institutions and as the highest organisation to oversee the national government school system. The development of Taixue and Guozhijian was thus confined to the limited range allowed by their Confucian ideologies.

Some Sinologists (see, for example, Hayhoe 1989), see the academies (書院) as an essential element of traditional Chinese higher education, stressing their private nature and freethinking atmosphere. Such features, however, were not always maintained. Sitting somewhere between the private and the official, the academies emerged in the late Tang dynasty, thrived from the Song to the Qing dynasties. Their longstanding historical developments bore a marked brand of ideological and financial control by the government. Initially they focused more on exploring Confucianism and personal intellectual cultivation than training government officials, with operating funds mainly from private donations. Such conditions, which could have become appropriate seed and soil for Western-style universities to grow, did not last long. In the Song dynasty, they became prosperous through winning recognition and financial support from government. The government extended its control via donations of books and lands. With gradual loss of independence from the government, the academies reached their peak during the Southern Song, became a major part of the government education system, and trained many officials. They were integrated into the government school system from the Yuan to the Qing dynasties, from the appointment of lecturers to examinations, admissions and the whereabouts of the students. By the Qing dynasty, their major aim had turned to be preparing for the imperial examination in the hope of winning an official rank (Zhang 2009, pp. 18-19).

Therefore, China started its higher education system with a fundamentally different relationship between the state and educational institutions from that of medieval universities, 
leading to a strong tradition of the alliance between education and politics in Chinese history. Ancient Chinese educational institutions have been far too reliant on their relations with the ruling elites. It is remarkable to see how these traditional ways of thinking have survived dramatic social and cultural changes in China's modern history, and how they remain deeply rooted among the Chinese people. It is precisely because of this that their impact on contemporary Chinese higher education is amazingly profound.

In stark comparison, medieval universities did not emphasise their physical spaces. Instead, they were a collection of individuals banded together as an universitas. They were autonomous corporations of students and masters, governed by internal rules set by the academic community itself and protected from the outset by Pope Gregory IX's bull. They were selffinancing, depending either on their properties or on contributions from students for their income. They were small, independent institutions catering to the elite and governed by their own members, who elected a rector (Mora 2001). More specifically, a few features distinguished Taixue and Guozijian from their counterparts in Europe: (1) their teaching staff received a government salary; (2) they took major classical texts of the Confucian school as their curricular content; (3) their teaching approaches included mainly lectures and self-study, with little argumentation.

\section{Attempts to indigenise the Western Concept of the University}

The strikingly different cultural roots and heritages have led to continuous conflicts between the traditional Chinese and the imposed Western system. Modern higher education systems have rarely been successfully practiced in the non-Western world, due to the constant tensions between the formal (visible), institutionalised and the informal (invisible yet powerful) systems within universities in non-Western countries, leading to overall ineffectiveness. This is particularly true in China: while Chinese higher education has been fundamentally operated within the traditional mode of thinking, the Western concept of the modern university has been taken by the Chinese for its usefulness. Such a stiff mix is not always questioned thoughtfully. To China, modern universities are an imported concept. They originated from Europe, spreading worldwide from the mid- $19^{\text {th }}$ century to the present time mainly due to colonialism. Even the countries that escaped colonial domination adopted Western models as well (Altbach 2001). The European-North American university model has never been tolerant towards any other alternatives, leading to inefficacy of universities in non-Western societies.

Attempts to indigenise the Western idea of a university started, in a piecemeal way, with Matteo Ricci's arrival into China, which was the prologue to a massive play of China's embrace of Western learning. Educational ideas from the West were introduced to the then still highly Sino-centric Chinese society first by the missionaries including Ernst Faber (1839-99), Timothy Richard (1845-1919), William Alexander Parsons Martin (1827-1916), and Young John Allen (1836-1907). While they attracted little attention from mainstream Chinese thinkers, a few open-

mined thinkers such as Wei Yuan (魏源) and Xu Guangqi (徐光啟) began to explore Western universities. Based on those in their home countries, some of the missionaries established universities in China (Jin 2000, p. 10). Many others were heavily involved in the growth of Chinese modern universities. Charles Daniel Tenney, for example, was invited by Sheng Xuanhuai (盛宣懷) to be the Dean of Studies at Peiyang University (北洋大學) and remained at 
the post for 11 years. Modeled on Harvard and Yale, Peiyang University focused almost exclusively on practical subjects, with all its facilities imported from the United States. It trained many much-needed engineers, with a reiterated orientation for pragmatism. Its success was greatly due to the high official rank and great influence of its founder.

The Opium Wars forced more Chinese to open their eyes. Guo Songtao (郭高壽), China's first ambassador, was sent to the UK in 1876. He observed British universities carefully during his two year stay there. While most in the Qing government, including his own deputy in the UK, still held the "foreign craft" in contempt, Guo developed a far better understanding of the values underlying British universities and the vital role played by universities in nationbuilding (Fan 2002, p. 250). Echoing Guo was Yan Fu (嚴複) who saw more fundamental roles of education. He correctly pointed out that scientific rationality was the essence of Western learning, and called for a scientific spirit among the Chinese people. Such an understanding exerted wide and profound influence on Chinese intellectuals.

Efforts to indigenise the Western university model succeeded in varying degrees at various levels. Achievements were most evident at the individual level. Chinese thinkers, such as Cai Yuanpei (蔡元培) and Hu Shi (胡适), never stopped trying to combine the Chinese with the Western ever since the $19^{\text {th }}$ century. Cai Yuanpei deserved the highest tribute in this regard. Believing that education was the only way to rejuvenate China (Cai 1997, p. 94), he went to Germany in 1907 to obtain actual experience and enrolled at Leipzig University where he took courses in philosophy, aesthetics, anthropology and experimental psychology. He studied German universities from their historical and philosophical roots to daily operation, combining theoretical inquiry with personal experience and on-the-spot observation. He introduced German classical ideas of a university into China, and was able to undertake a courageous experiment when he was appointed Minister of Education by the government in 1911 and Chancellor of Peking University in 1917. His momentous years transformed the university from an official institution of the Qing dynasty, already rotten in thought and action despite the fact it had been established only recently, into a modern institution (Yang 2009). At Peking University, he strongly advocated free thinking principles and an all-embracing approach, which is now seen as the most fundamental characteristics of Peking University.

Built on the work done by Xue Fucheng (薛福成) and Zheng Guanying (鄭觀應) during the last decade of the $19^{\text {th }}$ century, Cai introduced the Humboldtian system into China. The system was a product of German Idealism and defined research as the main role of the university (Mora 2001). His success as a leader of a university was unprecedented and still without parallel nearly a century later. John Dewey even set a higher value on his remarkable leadership in comparison with the presidents of the most prestigious American and British universities (Feng 1992). His efforts focused mainly on typifying the transformation of Chinese education from ancient to modern form, giving expression to conflicts and integration between traditional and modern, and remoulding Peking University into a Western-model institution that is established by the government while tied in many ways to the traditional system. His attempt was to combine the Chinese educational spirit, especially Confucian and Mohist character building, with Western systems. He was joined by a few like-minded others including his successor Hu Shi, Mei Yiqi (president of Tsinghua University) and Zu Kezheng (president of Zhejiang University). However, none of the followers could accomplish as much as he had. 
An example of institutional success during this time period despite extreme hardships is the National Southwestern Associated University (西南聯合大學) in Kunming, which was the amalgamation of the three major national Universities of Tsinghua, Peking and Nankai when the Second Sino-Japanese War broke out between China and Japan in 1937. Over the eight years of war (1937-1945), the institution became famous nationwide for having and producing many of China's most prominent academics, scholars, scientists and intellectuals. In addition to struggling for physical survival, its staff and students spent the war years striving to uphold a model of higher education in which modern universities, based in large part on the American model, sought to preserve liberal education, political autonomy, and academic freedom. Within three years after the war of resistance ended with victory over the Japanese, the majority of the university community had returned to their north China campuses in Beijing and Tianjin, and was prepared to accept communist rule. Successful in the face of wartime privations, enemy air raids, and political pressure from the ruling party, the University's constituent universities eventually succumbed to communist rule. By 1952, the University’s ideal had been largely replaced with a highly politicised and technocratic model borrowed from the Soviet Union. Academic freedom and world-class qualities in teaching and research soon belonged to the past.

At the system level, the period of 1911 to 1927 saw the first real effort to establish a "university" in the sense of the defining values of autonomy and academic freedom. Within the period, a tremendous range of new higher education institutions also developed and flourished. Different strands of China's own evolving traditions linked up with various foreign influences, with America replacing Japan as the most favoured source of influence. Hayhoe (1996, p. 43) has rightly and sharply pointed out that the lack of central government provided Chinese higher education with the possibility of vigorous experimentation. It is also important to add that many Chinese scholars who returned from Western countries and Japan played a critical role in the development of higher education. Educational thought gradually matured, with eclectic foreign influences, particularly from America and Europe.

What needs to be emphasised is that it is not purely accidental that these relative successes were all achieved when the Chinese nation was plunged into an abyss of suffering. Although unfortunate and ironic, it shows the extremely limited room allowed by strong Chinese traditions for higher education institutions to manoeuver. While the successes at system and institutional levels were achieved when the state had little time and energy for them, Cai Yuanpei's success was largely due to his most senior status within the ruling party as one of the founders. His successful stories could hardly be replicated by others. Instead of creating a magic mechanism to delink university operation from the government, his achievement was made possible because of his personal relationship with the highest officials. Within a decade after his departure from Peking University, his influence weakened. Since then, government control over universities has become even tighter. Having lost their independence in the political system, universities are administered just like the other organs of the Chinese administrative machine.

The conflict between traditional Chinese emphasis on political pragmatism and the classical persistence in ontological significance of knowledge from the West never blended well. The ideal to integrate Chinese and Western ideas never materialised. Dominated by a mentality of catching up, the search for such integration has been, consciously and unconsciously, left aside and overshadowed by urgent practical demands.

\section{Unfinished Business: Integrating Chinese and Western Ideas of a University}


The idea of the university is arguably the most successful export of the West to the rest of the world. Elements of universities' long historical traditions directly affect global higher education and relations among academic institutions internationally. The export of the university, fuelled particularly by the rise and dominance of the English language, has helped the West effectively dominate world scholarship and cultural development ever since the global spread of the European-North American university model. China is no exception. The Western model influences the direction of change in Chinese institutions of higher education. Shifting from their previous reliance on the Soviet experience, today Chinese universities look to the most elite American counterparts for standards, policy innovation and solutions to their own development problems. The integration between Chinese and Western ides of a university remains unfinished business.

Contemporary university reforms in China are a combination of externally imposed standards forcing China to adopt international (usually Western, and often American) modes of education and administration, as well as voluntary and even enthusiastic acceptance of foreign standards of academic excellence. Most of the international models for reform used by Chinese universities are based on the American experience and gained through educational exchange. This is particularly the case for the most prestigious universities. For example, the proposed personnel reform at Peking University has been based almost entirely on the perceived US experience (Yang 2009). The grafting of American policies onto Chinese university structure is not always built on sound understanding of the cultural differences involved (Mohrman 2008, p. 42). In this sense, Gan Yang's (2005) accusation of Peking University reformer Zhang Weiying's shortage of US higher education experience on the one hand, and his almost entire reliance on the American experience on the other, is relevant. He remarked:

The more the Beida [Peking University] reform plan advertises emulation of the United States, the more often it reveals the absence of a fundamental understanding of the American system on the part of the people in charge at Beida...I can almost say with certainty that Mr. Zhang Weiying has never read any books about the American tenure system; otherwise he should know that the so-called "up-or-out" that he loves to cite is actually a simplified version of the regular statement "seven years up-or-out rule," sometimes also enunciated as "six years up-or-out," the meaning of which is "if you're not promoted in seven years, you go,” or "if you're not promoted in six years, you go.” This is because the probationary period at the great majority of American universities does not exceed seven years. (p. 72)

Like other reformers at Peking University such as Min Weifang (2004) who cites almost exclusively Harvard and Stanford Universities to legitimise their policy moves and states repeatedly that American research universities are the best in the world, Zhang Weiying (2004) enumerated the reasons for granting tenure to full professors and some excelling associate professors in his book The Logic of the University. He borrowed foreign experience especially the American practice to argue that by so doing, established professors would be provided with a security so that they can concentrate on their long-term basic research rather than work for quick success and instant benefits. He also emphasised the use of the tenure policy to give young junior academics some hope and initiative to work harder and better. 
However, the foreign tenure policy lost its real meaning when it was borrowed by Zhang. According to Chen Pingyuan (2006), the tenure policy promoted by the American Association of University Professors and the Association of University Teachers in Britain set up respectively in 1915 and 1919 was motivated neither by economic benefits nor by lifelong employment, but was designed to set up to protect ideological and academic freedom. It is a natural part of the longstanding idea of the university and shares the same roots with the modern university. It is neither a favour from nor a useful tool for the university authorities.

Gan Yang (2003) offered similar criticism of the proposed plan's failure to express any serious interest in protecting academic freedom. According to him, such a failure was not accidental. It shows that the advocates of the proposed reform were short of necessary knowledge of the policies practiced in the USA and the UK, something that had ironically been used by them to legitimise their reform plan. Like Chen Pingyuan, he insisted that the tenure systems in the US and British systems were designed to protect academic freedom instead of advocating market competition. In his eyes, the proposed reform plan at Peking University "has neither taken the clear and rational American system into serious consideration, nor has it taken reference from the sensible British system" (p. 11).

Instead, the proposed reform at Peking University aped the practices at the Hong Kong University of Science and Technology, which is another American model in Hong Kong. To Gan Yang, this was particularly unfortunate, as the Hong Kong University of Science and Technology was the least suitable model for Peking University. He remarked:

First, the Hong Kong University of Science and Technology is a brand-new university, with its first enrolment in October 1991. It does not have any problems with the unqualified academic staff members appointed previously. Secondly, the University enjoyed abundant funding right from the beginning, with a budget of HK\$3.5 billion approved by the Hong Kong Legislative Council. Finally, it is primarily a university of technology and science, without undergraduates students enrolled in the humanities and social sciences. This is a stark contrast to an old university like Peking University which is particularly renowned for its humanities. (Gan 2003, pp. 13-14)

The wholesale adoption of US plans may not be totally appropriate for a country with a very different history and cultural traditions. At a minimum, Chinese universities could benefit from studying the problems that have plagued American universities, learning from the examples of what not to do in the effort to reform China's higher education institutions (Mohrman 2005). There is an urgent need for critical examination of the long-term consequences of grafting American academic practices onto a Chinese base. American higher education is rooted in its history, culture and social needs to serve the American society. With strikingly different cultural values and heritages, the Chinese need to look at knowledge and its production outside China more critically.

Another illustrative example of the unfinished business is China's contemporary higher education policies, which demonstrate Deng Xiaoping's strategy of "groping for stones to cross the river” (摸著石頭過河). Here, ideologies are less important. Traditional differences in educational values were shelved. What was stressed most was the possible educational contribution to economic growth. By the 1980s, China had incorporated a series of measures from foreign experiences including decentralisation and market mechanism, without exploring 
the institutional support for and the ideological foundations of these approaches, which seemed to be effective only in a few major Anglo-Saxon societies. While the structure of Chinese education remained largely based on the former Soviet model, the reforms were clearly American oriented (Hayhoe 1989). Little serious work was done to explore whether American branches could be effectively grafted on a Soviet tree planted in a Chinese garden (Pepper 1990). China's emphatic determination to separate the advanced knowledge of Western capitalist countries from what were still perceived as "decadent ideas" and a "bourgeois way of life" had overtones of the formula devised in its early modernisation efforts: "Chinese learning as the substance, Western techniques for their usefulness” (Ayers 1971). The disaggregation of Western culture into positive and negative elements was arbitrary. There had been no real equilibrium between Chinese and Western learning, a basic premise of China's successful integration into the world community.

Since the 1990s, China's higher education policies have aimed at both qualitative and quantitative developments, including the Program for Education Reform and Development in China (1993), the Education Act of the People's Republic of China (1995), the 211 Project (initiated in 1995), the 985 Project (initiated in 1998), and the dramatic expansion starting from 1999. More recent is the quest for world-class universities, which is designated as one of China's key policy positions. It reflects the larger changes in Chinese society, as China moves to engage with the outside world and reforms its economy to adopt market principles. The desire to have internationally competitive universities provides impetus for China's best institutions to follow the lead of European and North American universities, from curriculum to financial practices to new governance structures, further enhancing the frame of reference in higher education policy and a fervent embrace of international norms, especially in the top layer of universities. However, as observed by Mohrman (2005), the notion of world-class status within China seems largely imitative rather than creative. In striving for international standing, top Chinese universities compare themselves with Oxford and Yale, but they lack the centuries-long history and financial resources of Western universities.

The latest policy initiative is the Medium and Long-Term Education Reform and Development Plan (2010-2020) approved by the State Council in May 2010. Considering that it is China's educational blueprint for the next ten years, it is expected to demonstrate the vision and determination of the Chinese leadership. In many areas where China is facing serious challenges such as disparity and quality in education, the policy has demonstrated technical preparedness. What it lacks, like its predecessors, is exactly what is required for a blueprint especially for a reemerging China, a country with the world's only continuous civilisation for thousands of years. The Plan could have been much more visionary to make cultural preparation for China's more well-round future global roles, instead of remaining confined to the long-term catch-up mentality. However, it continues to demonstrate prioritised economic considerations in educational policymaking (Sigurdson 2004). Economic development is the reference point in every part of the initiative, once again leaving knotty issues of culture and values aside.

\section{Concluding Comments}

Throughout the modern era, Western and Chinese learning have contended for hegemony. Education has always been a key aspect of reform efforts (Bastid 1988). Holmes (1984) argued that the transfer of policies and practices from foreign countries would only succeed if they did 
not do violence to classical Chinese concepts of knowledge and did not threaten the power of the scholar officials. Unfortunately, China's experience has showed that the transfer of Western practice conflicts with the Chinese traditions. Modern universities are a foreign transplant to China. Indigenous Chinese higher education institutions only shared superficial resemblance with the medieval university in Europe. The central purpose of China's modern higher education has been to combine Chinese and Western elements at all levels including institutional arrangements, research methodologies, educational ideals, and cultural spirit, a combination that brings together aspects of the Chinese and Western philosophical heritages. This, however, has not been achieved.

The emphasis has always been on use (用), with corresponding ignorance of body (體). The development of Chinese modern universities has always been confronted with the absence of both classical and modern ideas of a university. While Chinese longstanding traditions never attempted to seek the ontological significance of knowledge, practical demands, consciously and unconsciously, have always been the highest priority. As part of national reform agenda, China's contemporary policies are in continuity with reforms since the $19^{\text {th }}$ century. Throughout this period, Chinese universities have experienced ups and downs in putting into practice the then already popular vision of retaining "Chinese learning as the essence” while systematically incorporating the new knowledge essential to build the nation (Hayhoe 2005). This explains why the best experiment was achieved by the National Southwestern Associated University, and justifies the system’s best innovations during 1911-1927.

Today, China's strategy remains the same. At certain stage, such a strategy could be effective. China's universities beat India's in almost every international ranking. According to the latest Academic Ranking of World Universities conducted by the Graduate School of Education, Shanghai Jiaotong University (2010), China has Peking University and Tsinghua University in the top 200; Fudan University, Nanjing University, Shanghai Jiao Tong University, University of Science and Technology of China, and Zhejiang University in the top 300, Shandong University, Sichuan University and Sun Yat-sen University in the top 400, and 12 others in the top 500. China features 22 times in the top 500, and India only twice.

Nevertheless, the promise is doomed to be limited. China has a considerable distance to go before its aspirations to create truly world-class universities are fulfilled. In the present great leap forward in Chinese higher education, what has often been missing is attention to cultural and institutional establishments. An internationally recognised scholarly ethos may take longer to develop than many academic and/or political leaders in China are willing to admit. Simply buying state-of-the-art laboratory equipment or pushing for more journal articles will not guarantee the kind of intellectual atmosphere that has developed over centuries on European and American campuses. Although China's recent developments deserve to be noted, they could soon hit a glass ceiling (Altbach 2010).

China's universities have been able to improve their hardware considerably, while, as is always the case in China, the software building takes much longer. In order to be truly "worldclass," Chinese universities cannot afford to continue to avoid the important and dwell on the trivial. According to Pang (1986), universities as cultural institutions have three layers with materials on the surface, social institutions in the middle, and values at the core. China's import of the Western university model has been centred mostly on the material level, with some touches on social institutions, while the core of the Western model, such as academic freedom and institutional autonomy, has rarely been understood, let alone implemented. The idea that the Western university model could work well on Chinese soil has been mistakenly taken for granted. 
For long, Deng Xiaoping's aphorism “Black cat, white cat, who cares as long as it can catch mice" has been burnt into Chinese souls. It is now high time to notice the nature of the cat because the mice to be caught would definitely be different.

The Chinese experience has more general implications for comparative studies. While most people agree with Deutsch, Dominguez and Heclo (1981, p. 4) that "Without comparisons, we could neither talk nor think," it is equally important to understand the prerequisites for comparative studies. One such prerequisite is clearly defined context. Indeed, many abuses of comparative studies have been due to misuse of context. For example, in the studies of Chinese higher education, although the significance of China's societal factors are generally acknowledged, some have reached a conclusion of a swift rise of Chinese universities on a global stage, even trying to characterise it as a Chinese model; others have stressed the marketisation and corporatisation of the system, claiming that China is moving in line with the "global tides"; while still others have expressed their great concern about the sustainability of China's higher education development. A major reason for such differentiation lies at the inaccuracy and inconsistency in their defining of the Chinese context. Context is too often treated inadequately as static, consistent, all-embracing, and reasonable (positive). In this regard, the prominent Chinese scholar Pang Pu's (1986) thesis of cultural structures deserves our attention as comparativists.

\section{References}

Altbach, P. (2001). The American academic model in comparative perspective. In P. Altbach, P. Gumport \& B. Johnstone (Eds.), In defence of American higher education (pp. 11-37). Baltimore, MD: Johns Hopkins University Press.

Altbach, P. (2010). Enter the dragons? Not so fast. Times Higher Education, 17 June, 39.

Appadurai, A. (1990). Disjuncture and difference in the global cultural economy. Public Culture, 2(2), 1-11, 15-24.

Ayers, W. (1971). Chang Chih-tung and educational reform in China. Cambridge, MA: Harvard University Press.

Bastid, M. (1988). Educational reform in early twentieth-century China. Ann Arbour, MI: Centre for Chinese Studies, University of Michigan.

Bridges, D. (2001). The ethics of outsider research. Journal of Philosophy of Education, 35(3), 371-387.

Cai, J. G. (1997). Cai Yuanpei and modern China. Shanghai: Shanghai Science Press.

Cao J. Q. (Ed.), (1994). Route to the revival of Confucianism: A collection of works by Liang Shuming. Shanghai: Shanghai Far-East Publishing House.

Chen, P. Y. (2006). What is the university? Beijing: Peking University Press.

Crossley, M. with Jarvis, P. (2001). Context matters. Comparative Education, 37(4), 405-408.

Deutsch, K., Dominguez, J., \& Heclo, H. (Eds.), (1981). Comparative government: Politics of industrialised and developing nations. Boston, MA: Houghton Mifflin.

Ebrey, P. B. (1999). The Cambridge illustrated history of China. Cambridge: Cambridge University Press.

Fairbank, J. K. (1983). The United States and China. Cambridge, MA: Harvard University Press. Fan, J. Z. (2002). Lonely forerunner: A biography of Guo Songtao. Beijing: People's Literature Publishing House. 
Feng, Y. L. (1992). A short history of Chinese philosophy. Hong Kong: Taipingyang Publishing Co.

Gan, Y. (2003). The legality and legitimacy of university reforms. In L.Q. Qian \& Y.D. Gao (Eds.), Problems and reforms in Chinese universities (pp. 3-14). Tianjin: Tianjin People's Press.

Gan, Y. (2005). The Beida reform follows the example of "peach pickers” but should spend more time "planting peach trees". Chinese Education and Society, 38(1), 75-79.

Graduate School of Education, Shanghai Jiao Tong University (2010): Academic ranking of world universities. http://www.arwu.org/ARWU2010.jsp. Retrieved on August 302008.

Hayhoe, R. (1989). China's universities and Western academic models. Higher Education, 18(1), 49-85.

Hayhoe, R. (1996). China's universities 1895-1995: A century of cultural conflict. New York: Garland.

Hayhoe, R. (2005). Peking University and the spirit of Chinese scholarship. Comparative Education Review, 49(4), 575-583.

Henkel, J.E. (2006). Book review of A treatise on efficacy: between Western and Chinese thinking by François Jullien (Honolulu: University of Hawaii Press, 2004), Philosophy East \& West, 56(2), 347-351.

Hockey, J. (1993). Research methods-researching peers and familiar settings. Research Papers in Education, 8(2), 199-225.

Hofstede, G. (1981). Culture and organisations. International Studies of Management and Organisation,10(4), 15-41.

Hofstede, G. (1991). Cultures and organisations: Software of the mind. New York: McGraw-Hill. Hofstede, G. (2001). Culture's consequences: Comparing values, behaviours, institutions, and organisations across Nations. Thousand Oaks, CA: Sage.

Holmes, B. (1984). A comparativist's view of Chinese education. In R. Hayhoe (Ed.), Contemporary Chinese education (pp. 7-25). London: Croom Helm.

Jin, Y. L. (2000). Studies of modern Chinese universities. Beijing: Central Party Literature Press.

Jullien, F. (2004) A treatise on Efficacy: between Western and Chinese thinking. Honolulu: University of Hawaii Press.

Kreiger, S. (1982). Lesbian identity and community: Recent social science literature. Signs, 8(11), 91-108.

Mead, M. (1929). Coming of age in Samoa. New York: Jonathon Cape.

Meng, X. C. (Ed.), (1996). Collections of ancient Chinese works on education. Beijing: People's Education Press.

Merton, R. (1972). Insiders and outsiders: A chapter in the sociology of knowledge. American Journal of Sociology, 78, 9-47.

Min, W. F. (2004). Secretary Min Weifang's face-to-face interview with Chinese central television on the subject of Beijing University's personnel reform. Chinese Education and Society, 37(6), 38-47.

Mohrman, K. (2005). Sino-American educational exchange and the drive to create world-class universities. In C. Li (Ed.), Bridging minds across the Pacific (pp. 219-235). Lanham: Lexington Books.

Mohrman, K. (2008). The emerging global model with Chinese characteristics. Higher Education Policy, 21, 29-48. 
Mora, José-Ginés (2001). Governance and management in the New University. Tertiary Education and Management, 7, 95-110.

Nakamura, H. (1964). Ways of thinking of Eastern peoples: India-China-Tibet-Japan. Honolulu, Hawaii: East West Centre Press.

Nisbett, R. (2003). The geography of thought: How Asians and Westerners think differently...and why. New York: The Free Press.

Pang, P. (1986). Cultural structures and modern China. Social Sciences in China, 5, 81-98.

Pepper, S. (1990). China's education reform in the 1980s: Policies, issues, and historical perspectives. Institute of East Asian Studies, University of California, Berkeley.

Sigurdson, J. (2004). China becoming a technological superpower-A narrow window of opportunity. East Asian Institute, National University of Singapore.

Welch, A. (2010) The challenge of comparative research: A critical introduction. In L. Markauskaite, P. Freebody \& J. Irwin (Eds.), Methodological choice and design: Scholarship, policy and practice in social and educational research (pp. 187-201). Dordrecht: Springer.

Yang, R. (2002). Third delight: The internationalisation of higher education in China. New York: Routledge.

Yang, R. (2007). Comparing policies. In M. Bray, B. Adamson \& M. Mason (Eds.), Comparative education research: Approaches and methods (pp. 241-262). Hong Kong: Comparative Education Research Centre, University of Hong Kong and Dordrecht: Springer.

Yang, R. (2009). Enter the dragon: China's higher education returns to the world community. In J. Smart \& W. Tierney (Eds.), Higher education: Handbook of theory and practice (pp.431-467), Dordrecht: Springer.

Yuan, Z. (1994). Local government schools in Sung China: A reassessment. History of Education Quarterly, 34(2), 193-213.

Zhang, W.Y. (2004). The logic of the university. Beijing: Peking University Press.

Zhang, Y. (2009). Western ideas of a university in China: Introduction and impact. Hangzhou: Zhejiang University Press.

Zheng, D.Y. (1994). History of Chinese higher education. Shanghai: East China Normal University Press.

Zhou, Y.T. (1934). History of modern Chinese education. Beijing: Beneficial Friends Publishing Company. 